Reference Services Review. 1987. vol.15, iss. 1, pp.23-28.

ISSN: 0090-7324

DOI:10.1108/eb048971

http://www.emeraldinsight.com/products/journals/journals.htm?id=rsr

http://www.emeraldinsight.com/journals.htm?issn=0090-7324

http://www.emeraldinsight.com/journals.htm?issn=0090-7324\&volume=15\&issue=1\&articleid=1696050\&show=ab

stract

(C) 1987 MCB UP Ltd

\title{
City Planning Biography: Selected References
}

\section{Jane McMaster}

\section{INTRODUCTION}

Interest in the origins and history of city planning in the United States has made it necessary to provide more information about biographical and reference sources on the subject. In tracing the evolution of American city planning, it is often necessary to identify individuals active, for the most part, during the period from 1900 to 1950, who are significant either for the roles they have played in the development of particular cities or regions, or for their advocacy of particular planning principles. Anthony Sutcliffe, who organized the first International Conference on the History of Urban and Regional Planning in 1977, points out the importance of city planning biography in his book, The History of Urban and Regional Planning; An Annotated Bibliography (1981). In the introduction to his chapter on individual planners, he notes the "great attraction of the biographical approach to planning historians" (139).

Because no adequate comprehensive works of biography exist for the city planning field, it is important for librarians serving this discipline to identify a wide range of potential sources. ${ }^{1}$ This information comes in several forms, both as part of the general tradition of collected biography, and as it relates to the literature of the city planning movement in the United States. There are indexing and bibliographical sources, short entry directories, encyclopedic essays, and historical sources in which biographical information is secondary to the purpose of the publications.

There are at least three reasons for the lack of comprehensive biographical works for the planning profession. City planning in the United States is a comparatively new field (it began to evolve around the turn of the century). The interdisciplinary nature of the profession is evident in the array of occupations of its early practitioners: landscape architecture, civil engineering, law, real estate, architecture, social reform, and publishing. Second, the first three decades of this century saw heavy grassroots involvement in the field. Citizens formed civic betterment committees and business leaders fostered involvement through local chambers of commerce. Third, city planning was not immediately recognized as a separate profession. The first degree-granting program in planning was established in 1929 at Harvard University. ${ }^{2}$ The occupational index to the twenty-volume Dictionary of American Biography, published in 1937, has only three names under the heading for city planners. Biography Index, an H.W. Wilson publication that began in 1946, did not recognize the planning profession in its occupational listing until the fourth cumulated volume was published in 1960. Since its inception in 1940, Current Biography has never had a designation for city planners in its occupational index.

The interdisciplinary nature of American city planning, heavy citizen involvement across the country, and the delay in its being recognized as a profession all helped to retard the production 
of adequate biographical information. Sources to remedy this situation are discussed below, beginning with general biographical references and moving to more specific titles relevant to the field of city planning and its related disciplines.

\section{GENERAL BIOGRAPHICAL SOURCES}

In trying to research names in city planning, it is profitable to start with the most comprehensive biographical reference publications, especially if the individuals have not been prominent nationally or their precise affiliations are unknown. The title that offers the broadest coverage of living individuals is the Biography and Genealogy Master Index, published in 1981 by Gale Research Company. It was originally issued in eight volumes and has been kept up to date since then by annual supplements. This set lists over three million names from 350 collective biography titles, most of which follow a short entry directory format.

A companion to the Biography and Genealogy Master Index is the Historical Biographical Dictionaries Master Index, published by Gale in 1980 in one volume. It consolidates biographical information, from over thirty-five retrospective historical biographies, on 300,000 deceased individuals.

The Personal Name Index to the New York Times (1976-) is another comprehensive source for tracing people who are not widely known. The initial fourteen-volume set treats the period from 1851 to 1974; there have been ongoing supplements since 1975. Another good tool that uses New York Times information is the New York Times Obituaries Index, 1858-1968 (1970) which, together with a supplement for the years 1969 through 1978, cumulates 400,000 references to obituary notices that have appeared in the Times during those years.

Among the collective biography sources that offer essays, the most useful for the field of city planning is the National Cyclopedia of American Biography (NCAB). Though it is written by staff members and does not offer critical assessments of its biographees, it does have a history of continuous publication since 1892 and now numbers over 50,000 entries. Because of its less stringent selection policy, many locally prominent businessmen, educators, and public officials who have had an interest in civic improvements are profiled in the NCAB. Its weaknesses include the lack of signed articles with appended bibliographies, and the fact that none of the seventy-five volumes in this set is arranged alphabetically. There is, however, an accurate and well-organized cumulative index for all the volumes issued through 1984.

The Dictionary of American Biography (DAB), while it is not as comprehensive as the $\mathrm{NCAB}$, does have more than 17,000 biographies that have been contributed by approximately 3,000 scholars. Each entry is signed and lists useful bibliographic references. To date, seven supplements have been published, addressing the period 1936 to 1965 . The DAB is purposely less timely to ensure that the biographee has earned a lasting place in American history as a nationally prominent figure.

Another source of retrospective biographical sketches is Who Was Who in America. It comprises profiles that have been removed from the Who's Who in America editions because the subjects are deceased. It is most beneficial in tracing individuals who are no longer prominent enough to appear in the standard retrospective dictionaries like DAB and NCAB. The historical volume treats the years 1607 through 1896 and the subsequent companion volumes pertain to the years 1897 through 1985, for a total of 105,000 entries. There is a cumulative index for the period 1607 through 1981. 


\section{BIOGRAPHICAL SOURCES IN CITY PLANNING AND RELATED DISCIPLINES}

To focus more narrowly on the field of city planning and its related disciplines, it is necessary to examine other titles of biographical interest--both primary sources and those for which biographical information is a secondary concern. Publications based on the collections of the Avery Memorial Architecture Library at Columbia University are very important resources. The Avery has three major ongoing reference tools that shed light on the development of American city planning. The first is the Avery Obituary Index of Architects (second edition, 1980), which lists obituaries of approximately 17,000 architects, landscape architects, and city planners. These obituaries appeared in newspapers and more than 500 journals--some dating from as early as 1843 . The significance of obituaries is that, rather than offering just a short objective report on a person's life, as some of the directory sources do, obituaries usually attempt to evaluate the individual's contribution to his or her field, and highlight his or her career achievements. The Avery Library also compiles the Avery Index to Architectural Periodicals (1973-), which provides access to over 500 serial publications--many dating from the late 1800s, and the A very Memorial Architectural Library Catalog (1968 and supplements), which lists by subject all of the more than 200,000 volumes in the library's collection.

The fiftieth anniversary of the 1917 founding of the first professional planning organization, the American City Planning Institute (known today as the American Planning Association) was the occasion for the publication of two histories that are invaluable for biographical research. The first is Russell Van Nest Black's Planning and the Planning Profession (1966). It provides a concise overview of the development of the American city planning movement, which includes brief biographies of twenty-five of the charter members of the American City Planning Institute and short vignettes on the accomplishments of the twenty-eight planners who received the American Institute of Planners Distinguished Service Award between its inauguration in 1953 and the year that the book was published. The other history, American City Planning Since 1890 (1969) by Mel Scott, is a monumental survey of planning in this country from the 1890 s to the 1960s. While this is not a critical work, the subject and name indexes list more than 400 planners, and Scott's narrative places them in context so that the researcher has clues to follow for further information.

A more recent work, titled The American Planner: Biographies and Recollections (1983) and edited by Donald Krueckeberg, offers chapters on approximately twenty important planning figures, largely reprinted from the AIP and APA journals. It also includes a detailed index for retrieving information on the many others who are mentioned in the book but who are not the subjects of chapters.

\section{BIOGRAPHICAL SOURCES IN THE LITERATURE OF PROFESSIONAL PLANNING ORGANIZATIONS}

In some instances, stand-alone bibliographies have been devoted to citing works by and about an individual planner. Such is the case for John Nolen \{John Nolen, Landscape Architect, Town, City and Regional Planner; A Bibliographical Record of Achievement (1976) by John Hancock); Thomas Adams \{Thomas Adams: A Biographical and Bibliographical Guide (1978) by John Hulchanski); and Frederick Law Olmsted \{Frederick Law Olmsted, Landscape Architect, 
Urban Planner (1979) by Christine Moe, Vance Bibliography 147).

But these in-depth resources are the exception rather than the rule; there is a paucity of bibliographical tools on those legions of citizens and professionals, prominent in their own communities, who have not merited a great deal of individual attention but who have made a significant contribution to the advancement of city planning nationwide. In many cases, the only way to identify these people is through the articles they wrote or the speeches and papers they presented at professional meetings. One example is King Thompson, a real estate developer, who built the community of Upper Arlington, a suburb of Columbus, Ohio. In nominating the original residential district of Upper Arlington to the National Register of Historic Places, preservationists needed to determine Thompson's philosophical objective in laying out the town as he did. They were able to find a speech that he delivered to the seventh National Conference on City Planning (1915) which outlines his plan and the "City Beautiful" influences from which he drew it. ${ }^{3}$

Apropos of these lesser known figures, it is fortunate that great attention was paid to the early organization and recording of the professional literature by several individuals and by the fledgling professional organizations. Theodora Kimball Hubbard and her husband, Henry, are responsible for much of this organization. In $1911 \mathrm{Mrs}$. Hubbard became the first librarian for the Department of Landscape Architecture at Harvard University, and her husband was said to be its first graduate with city planning training (1901). Mrs. Hubbard, along with Harvard faculty member James Sturgis Pray, devised the first classification scheme for city planning literature. ${ }^{4}$ She also contributed articles and reviews to several planning magazines, ${ }^{5}$ collaborated with her husband on several books ${ }^{6}$ and co-edited the Landscape Architecture magazine with him from 1918 to 1935 . In addition, she prepared bibliographies on many planning subjects, the most comprehensive of which is the Manual of Information on City Planning and Zoning (1923) organized using her classification scheme. It includes a section on biography and also has author and subject indexes. Supplements were issued in 1928 and 1936.

Other comprehensive bibliographies published after 1936 that offer good author and subject access (essential for tracing articles by and about some of the lesser known figures in American city planning) are Samuel Spielvogel's A Selected Bibliography on City and Regional Planning (1951); Melville Branch's Comprehensive Urban Planning; A Selective Annotated Bibliography (1970); and George Bestor and Holway Jones's City Planning Bibliography; A Basic Bibliography of Sources and Trends (third edition, 1972).

The formation of the National Conference on City Planning in 1901 marked the beginning of annual opportunities for professional planners and interested laypersons to meet, deliver papers, and exchange ideas about the aims of city planning. The conference issued a published volume of each year's proceedings, and in 1927 compiled a cumulative index to the first eighteen meetings. This index helps immeasurably in identifying the participants and their remarks, and, as noted in the Thompson example above, is a great resource of information on some of the more obscure individuals of the time.

Three distinct groups emerged to advance the cause of planning. In 1934 the National Conference on City Planning and the American Civic Association joined forces to become the American Planning and Civic Association, primarily to serve the public-spirited citizen's interest in planning. The American Society of Planning Officials was born the same year to provide a voice for the growing number of public administrators with a stake in city planning. The American City Planning Institute (which became the American Institute of Planners in 1938) remained to serve the professional city planner.

In 1929, the American Civic Association (formed in 1904 by the merger of the American 
Park and Outdoor Art Association and the American League for Civic Improvement) began publishing the American Civic Annual. It was issued yearly until 1935, and it included short articles by distinguished planners and a directory section called "Who's Who in Civic Achievement." In 1935 the title changed to The American Planning and Civic Annual. While short articles by planners and experts in related fields continued to appear, difficulty in obtaining information on the greatly expanded joint membership led them to omit the "Who's Who" section. Until it ceased publication in 1957, the Annual provided intermittent short vignettes on the fifty to eighty people who wrote articles or reported on sessions in a section called "Our Contributors."

The American Society of Planning Officials (ASPO) supplied continuity for the annual proceedings that had been sponsored by the National Conference on City Planning and the American City Planning Institute. ASPO continued publishing proceedings from 1934 until 1971. A cumulative index to the first fifty-two meetings was compiled in 1962 by Mary Vance, Librarian for the Department of City Planning and Landscape Architecture at the University of Illinois. It was titled ASPO Index to Proceedings of the National Planning Conferences, 1909-1961, and it listed alphabetically the authors and subjects of, and geographic locations mentioned by, papers presented at the meetings. A supplement to this work has been done by John Worsham and was issued as number 297 of the Public Administration Series of Vance Bibliographies; its title is Planning, an Author and Subject Index to the Selected Papers from the ASPO National Conferences, 1960-1971.

The American Institute of Planners did provide some written record of its annual meetings, though it is neither complete nor indexed. From 1958 to 1965, American Institute of Planners Report of the Proceedings was issued. Volumes containing selected papers were published intermittently beginning with the fifty-eighth annual conference in 1975, but ceased altogether after the 1981 American Planning Association Conference in Boston. Except for a few scattered issues, no indexing is available for this set; however, by scanning the table of contents for each, the researcher can discover the authors and titles of all papers that are represented.

\section{BIOGRAPHICAL SOURCES IN PROFESSIONAL PLANNING JOURNALS}

At least two journals important to the field of city planning should be mentioned as sources of biographical information because of their broad treatment of the discipline and because they are extensively indexed. The first is Landscape Architecture, founded by Henry Hubbard in 1910 and edited by him until his death in 1947. (His wife, Theodora, served as co-editor until her death in 1935.) Landscape Architecture was one of the first journals to carry extensive planning information. In 1930, it published a cumulated index to the first twenty years' issues with an author index, a subject subdivision on biography, and a section on obituaries and memorials. Bruce Ferguson, a professor of landscape architecture at the University of Georgia, has recently compiled a more inclusive cumulative index to Landscape Architecture, covering the years 1910 to 1982. In addition to listing all those who have written articles during this period, he has also compiled a list of all persons and organizations that have been the subjects of articles.

The American Planning Association has furnished excellent access to its premier journal from its inception as City Planning in 1925, with Henry Hubbard as its editor, to the present Journal of the American Planning Association. A cumulative index covering the preceding thirty-three years was published in 1958, and in 1983 a cumulative index to the most recent twenty-five years was produced. It features one alphabetical list of authors, titles, and subjects. There are separate sections for book reviews, correspondence, plan reviews, and editorials. One of 
the subject headings is "Planners," and under it is listed fifteen articles about individual planners.

\section{MISCELLANEOUS SOURCES OF PLANNING BIOGRAPHY}

Two sources that deal with planning on an international level should be mentioned for their treatment of American planners. The first is Arnold Whittick's Encyclopedia of Urban Planning (1974). Though it restricts the subjects of its biographical entries to those who have "...contributed something original, unique, or distinctive to the art and science of urban, regional and country planning...or who have originated...important new planning policies" (Preface, p. xix), the essays are excellent and are signed by the contributors. A helpful bibliographical note follows each entry.

The other reference that should be consulted for biographical citations is Anthony Sutcliffe's History of Urban and Regional Planning; An Annotated Bibliography (1981). His section on individual planners, mentioned earlier, cites useful and somewhat obscure material about more than fifty planners worldwide.

\section{ARCHIVAL SOURCES OF PLANNING BIOGRAPHY}

Archival records can be a rich source of primary biographical research material. The majority of papers by and about planners and planning organizations have been collected by Cornell University's Department of Manuscripts and University Archives. Currently the archives hold more than one hundred collections of interest to the planning historian. A checklist identifying this material is available from the department for a nominal charge. Cornell's city and regional planning program celebrated its fiftieth anniversary in 1985, and to mark the occasion the Department of Manuscripts and University Archives prepared an exhibition titled "Urban America: Documenting the Planners." The exhibition catalog offers a concise history of the profession, while showcasing many of the important items from the papers that are housed at Cornell. A section at the end of the catalog lists the Cornell collections that document the history of American city and regional planning.

A promising new source of archival information is the National Inventory of Documentary Sources in the United States, which began publication in 1984. This comprehensive microfiche reproduction of finding-aids to archives and manuscript collections around the country consists of four parts and a printed index. Part one, "Federal Records," covers the National Archives, the Smithsonian Institution Archives, and the Presidential Libraries; part two, "Manuscript Division of the Library of Congress," covers 772 LC collections; part three covers state archives, libraries, and historical societies; and part four covers academic libraries and other repositories. This resource not only helps one to locate an individual's papers, but also gives invaluable aid in describing the organization of the collection and its relevant parts.

\section{CONCLUSION}

The resources mentioned above are intended to assist in the process of discovering information about American city planners, but many of the works also help to answer inquiries about the development of individual cities and regions as well as the history of the city planning movement generally. The major focus of these publications has deliberately been on the period 1900 to 1950. It is left to some braver soul to deal with research options for the more anonymous planning bureaucracy that was created in the aftermath of the Federal Housing Act of 1949. 


\section{NOTES}

1. The only reference to United States city planning biography in the initial volume of Robert Slocum's Biographical Dictionaries and Related Works; An International Bibliography of Collective Biographies (1967) or its two supplements (1972 and 1978), is "Who's Who in Civic Achievement" published as part of the American Civic Annual from 1929 through 1934.

2. Frederick J. Adams and Gerald Hodge, "City Planning Instruction in the United States: The Pioneering Days, 1900-1930," Journal of the American Institute of Planners 31 (February 1965): 43.

3. Proceedings of the Seventh National Conference on City Planning, 1915, 84-87. Cambridge, MA: Harvard University Press, 1915.

4. James Sturgis Pray and Theodora Kimball Hubbard, City Planning; A Comprehensive Analysis of the Subject Arranged for the Classification of Books, Plans, Photographs, Notes and Other Material. (Cambridge, MA: Harvard University Press, 1913).

5. Among them were American City, National Municipal Review, City Planning, and Landscape Architecture.

6. She co-authored with her husband, Henry V. Hubbard, An Introduction to the Study of Landscape Design (1917), Landscape Architecture - A Comprehensive Scheme (1920), and Our Cities Today and Tomorrow (1929). 